\title{
HOMEM DE LETRAS, INTELECTUAL, LÍDER
}

Homme de Lettres, ou, em uma designação menos sexista, Gens de Lettres, foi a expressão que, nos séculos XVII e XVIII, os franceses cunharam para dar conta da ação dos estudiosos da literatura, da cultura e das ciências que podiam servir ao Estado, mas que não necessariamente se envolviam em política fora dos quadros de preferência acadêmicos. No Brasil do século XIX e da primeira metade do século XX, o termo poderia incorporar pensadores e intelectuais, os quais, formados sobretudo em Ciências Jurídicas ou em Filosofia, atuavam na imprensa e lecionavam no ensino superior, que dava seus primeiros passos em nosso país.

A expansão do ensino universitário e o estabelecimento de uma política de fomento à pós-graduação e à pesquisa subverteram em parte o conceito tradicional de Gens de Lettres: substituíram o arcabouço universalista e náo especializado pela expertise e pela necessidade do compromisso com a formação de recursos humanos, que convertem o apreciador da literatura em docente, orientador e pesquisador, cuja visibilidade se traduz em publicaçôes científicas, qualificadas por avaliaçôes contínuas.

José Luís Jobim preenche com naturalidade o novo desenho do professor, intelectual e pesquisador brasileiro. Graduou-se e doutorou-se em Letras, completando sua formação com estágio pós-doutoral nos Estados Unidos. Leciona em duas das mais importantes universidades brasileiras, a Estadual do Rio de Janeiro e a Federal Fluminense. É pesquisador reconhecido, de que dáo testemunhos bolsas concedidas por agências federais, como o CNPq, e estaduais, como a FAPERJ. Presta consultoria a órgãos de fomento e avaliação, como CAPES, INEP e FAPESP, além dos mencionados CNPq e FAPERJ.

Esse retrato, contudo, não esgota a apresentação do homem de Letras que é José Luís Jobim, acrescentando-se ao desenho outro fator essencial, capaz de especificar o que é contemporaneamente pertencer ao mundo da literatura e da cultura: significa escolher participar da elaboração de políticas públicas para o campo intelectual a que a pessoa se vincula, abrindo máo da posição contemplativa com que muitas vezes se representa o pesquisador.

José Luís Jobim, que presidiu a Associação Brasileira de Literatura Comparada (ABRALIC) e colaborou com a diretoria da Associaçáo Nacional de Pós-Graduação e Pesquisa em Letras e Linguística (ANPOLL), ilustra bem o perfil da "gente de Letras" de nossos dias. E o fez com grande 
competência, haja vista seu permanente comprometimento com as duas principais associaçóes da área de Letras em nosso país.

Outro fato essencial que particulariza a ação do intelectual em nosso tempo decorre do alcance e impacto das pesquisas realizadas. Vocacionado para o estudo teórico da literatura, José Luís Jobim dedicou-se primeiramente à reflexão sobre os fundamentos da Ciência da Literatura. No começo dos anos 1990, organizou uma coletânea fundamental para os estudos literários nacionais, Palavras da crítica: tendências e conceitos no estudo da Literatura, em que sistematiza, com o apoio dos autores que participam da obra, as noçôes básicas das Teorias Literárias vigentes no século XX. A poética do fundamento: ensaios de teoria e história da literatura, de 1996, Introduçáo aos termos literários, de 1999, e Formas da Teoria - sentidos, conceitos e campos de força nos estudos literários, de 2002, são livros que levam adiante o empenho por construir uma Teoria da Literatura apoiada na experiência brasileira, sem perder de vista a contribuição internacional.

$\mathrm{O}$ conhecimento teórico levou o pesquisador a investigar as consequências históricas de conceitos básicos. Assim, voltou-se à discussão de um tema reincidente na tradição brasileira - o "nacionalismo", matéria de discussóes que, oriundas do século XIX, persistem no século XXI, endossando-o ou opondo-o a noçōes como as de globalização. Evitando a polarização contraproducente, o pesquisador propóe uma reflexão sobre o trânsito entre culturas e espaços distintos, passagem que faculta resistir às teses, hoje descartadas, relativas à "influência" ou à "dependência" de uma sociedade ou civilização sobre outra.

O exame do que o pesquisador denomina "trocas e transferências literárias e culturais" permite retomar termos da Teoria da Literatura que não apenas conceituam, mas que avaliam produçóes artísticas, como imitação ou originalidade, autonomia ou sujeição, facultando, ainda, perguntar pelo lugar do Brasil e da América Latina na elaboração de um pensamento que extravase fronteiras geográficas e intelectuais. Os resultados dessas propostas medem-se em livros publicados nos últimos anos, como Trocas e transferências culturais: escritores e intelectuais nas Américas, de 2008, lançado em 2009 na Inglaterra, com o título Cultural Transfers and Exchanges: From National to Transnational Blocks, e Literatura e cultura: do nacional ao transnacional, de 2013.

Cabe mencionar duas outras linhas de investigação abrigadas pela ação intelectual e liderança de José Luís Jobim: em meados dos anos 1990, capitaneou pesquisa sobre a biblioteca de Machado de Assis, instigado pelo ensaio pioneiro de Jean Michel Massa dedicado ao tema. Desse trabalho 
coletivo resultou a obra de referência fundamental, A biblioteca de Machado de Assis, impressa em 2001. Se, diante de Machado de Assis, Jobim buscou atar as pontas entre o passado das leituras do Bruxo do Cosme Velho e o que resta desse universo de livros, diante da pós-modernidade, ele não deixou de se posicionar quanto às modificaçóes dos suportes que conduzem a produção literária a novas alternativas, objeto de Literatura e informática, de 2005.

Permanentemente dinâmico diante dos novos desafios, José Luís Jobim sumaria a "gente de Letras" do novo século, e todos que participamos desse universo sentimo-nos muito orgulhosos de tê-lo como companheiro e líder nessa jornada.

Regina Zilberman (UFRGS/CNPq) 